\title{
Application of Blended Learning for Formation of Project Competence of Future Engineers
}

\author{
https://doi.org/10.3991/ijep.v10i3.12251 \\ Olga V. Galustyan $\left({ }^{\square}\right)$ \\ Southern Federal University, Rostov-on-Don, Russia \\ olga.galustyan@gmail.com \\ Alexey V. Solyankin \\ State University named after A.N. Kosygin, Moscow, Russia \\ Alina V. Skripkina, Evgeny A. Shchurov \\ Moscow University of the Ministry of Internal Affairs of the Russian Federation \\ named after V. Y. Kikot, Moscow, Russia \\ Tatyana V. Semeshkina \\ State University named after A.N. Kosygin, Moscow, Russia \\ Anastasia V. Ledeneva \\ Orenburg State Pedagogical University, Orenburg, Russia
}

\begin{abstract}
The article is devoted to application of blended learning for formation of project competence of future engineers. The article identifies the main characteristics of blended learning as means of development of project competence of future engineers. Project competence is characterized by the ability of future engineers to apply knowledge, skills and personal qualities, that ensure readiness for implementation of project activity and awareness of personal responsibility for the results of this activity. Structure of project competence of future engineers is presented by cognitive, operational, communicative and reflexive components. The authors conclude that application of blended learning satisfies the needs of modern engineering education.
\end{abstract}

Keywords - Blended learning, project competence, ICT tools, future engineers

\section{Introduction}

Modern transformations in education are characterized by the constant increase of requirements for the quality of professional training of graduates of higher educational institutions $[2,5,12]$. At the same time, project paradigm is of the key importance as basis of reorganization and innovative processes of education. Modernization of engineering educational process involves introduction and development of project skills of future engineers. The task of future engineers is to develop competencies and skills which enable them to implement integrated projects and initiatives $[9,16,25]$. 
Furthermore, informatization of engineering education meets the needs of the modern educational process $[1,6,14]$. Vocational engineering education should serve as a factor of development of engineering activities. Engineering universities are to participate in the working out and development of technical systems and technologies actively in order to search for the optimal solutions for professional tasks which future engineers are facing. Development of forms and methods of engineering activities includes ability of engineering universities to teach the students project working methods $[11,13,26]$. Blended learning contributes to formation of project competence of future engineers. It engages future engineers in active cognitive, communicative, practical and other types of activities in order to solve various problems of project training.

\section{Methods Used During A Research Project}

$[7,22]$ consider that project training is focused on solving problems which involve, on the one hand, use of various teaching methods and means, and, on the other hand, integration of knowledge and skills from various fields of science, engineering and technology.

Project training is understood as organization of self-regulated activities of small group of students within the process of creating project with presentation of its results.

Summarizing the ideas of $[19,23]$ we conclude that project training is aimed at formation of the following skills:

1. An ability to understand the essence of informational processes in engineering and society.

2. An ability to understand the essence of design and technological IT activities.

3 . An ability to think creatively and to generate new ideas.

4. Skills of theoretical and experimental research, design and construction work.

5. According to $[8,15,20,26]$ the following tasks should be achieved as a result of project training.

6. Formation of ideas concerning general engineering activities.

7. Development of students' interest for engineering profession.

8. Motivation for engaging students in engineering activities.

9. Assistance to the students in choosing individual educational path within the framework of their specialty.

10. Satisfaction of students in their individual intellectual development;

11. Formation of system interdisciplinary thinking and independence in design of technical systems.

12. Development of ability of creative thinking while making new effective technical solutions and solving of engineering problems.

13. Formation of ability of systematic purposeful search and informed choice of new effective engineering solutions.

14. Development of skills of analysis of intermediate results of individual or group activities. 
15. Development of skills for the practical implementation of the proposed solutions in creation of projects.

16. Formation of sense of responsibility for the result and for the quality of the created product.

It should be noted that work on the project does not need constant presence in a classroom and constant collaborative work. Therefore, we consider blended learning as the most suitable pedagogical strategy for the development of project competence.

Blended learning combines face-to-face education and e-learning that makes it possible for the students to choose suitable time, place, pace and trajectory of learning $[4,17,24]$.

Thus, it allows to use the advantages of face-to-face education and e-learning more and to compensate the disadvantages of each other. Blended learning has broad prospects for use and further development of engineering education and for formation of project competence of future engineers [3, 21].

Scientists $[10,18,27]$ consider that application of blended learning in formation of project competence of future engineers allows to form:

1. Critical thinking, ability to select reliable data sources and to select information that is necessary to solve a problem.

2. Creativity, ability to rethink existing information, to synthesize new ideas and solutions.

3. Teamwork, ability to interact with the other people productively, to look for likeminded people and to create teams.

4. Ability and desire to learn throughout life.

5. Ability to make decisions and to bear responsibility for them.

Blended learning like any other innovative technology takes time and extra effort from the part of a teacher. While using blended learning, the main emphasis is done on the formation of work skills, group work, mutual assistance and communicative competencies unlike the classroom lesson system, where the main time is spent on the formation of training skills and establishment of discipline in class.

\section{$3 \quad$ Materials and Methods}

\subsection{Participants}

We conducted our experiment at Southern Federal University (Rostov-on-Don) and State University named after A.N. Kosygin (Moscow) in 2018-2019. 311 students and of specialty "Environmental Engineering" took part in the experimental work. Students who participated in the study were from 20 to 22 years of age. The experimental group of 155 participants was trained based on blended learning. The control group of 156 participants was taught within face-to-face education. 


\subsection{Methods of blended learning}

We used various types of digital educational resources and online services within formation of the project competence of future engineers by means of blended learning in the experimental group:

1. Learning management systems (Moodle, Edmodo).

2. Tools for creating and publishing content and training objects (1C test designer).

3. Tools for communication and feedback (Vebinar.ru, Skype, Google Chat.).

4. Tools for collaboration (Google Docs).

5. Tools for creating communities (social network Facebook).

6. Tools for planning educational activities (electronic journals).

Organization and implementation of project activity was carried out according to the following plan:

1. Working out of technical specifications of the project.

2. Working out of project schedule.

3. Selection of candidates for participation in the project.

4. Distribution of responsibilities for the participants of the project.

5. Implementing of the project by the group of participants.

6. Public presentation of the project results.

7. Assessment of the work by the participants (filling in evaluation sheets).

8. Preparation of documentation of the project.

\subsection{Project training}

Formation of the project competence of future engineers by means of blended learning in the experimental group included students' research work. It included choice of the topic; definition of object and subject of research work, its goals and objectives; development of hypothesis; working with literature; choice of research methods; collecting materials; conducting research; processing of the results of the study; formulation of conclusions.

During the project activities students prepared projects on such topics as "Special Vehicles", "Testing of Special Vehicles", "Units and Mechanisms of Vehicles", "Professional Activity of Engineers", "Optimal Workplace of a Software Engineers", and etc.

We used group project tasks aimed at mastering algorithm of project actions. We also conducted extra-curricular activities for students such as creation of students' scientific community, excursions to the objects of the engineer's activities, study of documentary materials. These activities served as the basis for formation of the idea concerning project activities, their role in the engineering professional activities, interest of future engineers in project activity for participating in it. 


\section{$4 \quad$ Results}

Experimental work was conducted in order to identify the level of project competence in the experimental and control groups at the beginning and at the end of the experiment. We consider that project competence is an integrative characteristic of future engineer. Project competence is expressed in personal and professional development as a result of project activities at procedural and operational levels.

Project competence includes cognitive, operational, communicative, and reflexive components. Structure of project competence is reflected in Table 1.

Tables 2 and 3 show dynamics of step-by-step development of project competence.

Table 1. Structure of project competence

\begin{tabular}{|l|l|}
\hline \multicolumn{1}{|c|}{ Component } & \multicolumn{1}{c|}{ Characteristic } \\
\hline Cognitive component & $\begin{array}{l}\text { Analysis and evaluating of information } \\
\text { Formulation of the problem } \\
\text { Understanding of the subject matter of the project } \\
\text { Setting of the goals of project activities } \\
\text { Planning of project activities, design of the final product. }\end{array}$ \\
\hline Operational component & $\begin{array}{l}\text { Ability to organize and to regulate project activities } \\
\text { Ability to monitor, to adjust and to evaluate project activities } \\
\text { Ability to apply subject knowledge and methods of activity in project } \\
\text { activities. }\end{array}$ \\
\hline Communicative & $\begin{array}{l}\text { Ability to carry out communicative actions within project activities } \\
\text { organization and planning of educational cooperation with members of project } \\
\text { team. }\end{array}$ \\
\hline Remponent & $\begin{array}{l}\text { Ability to evaluate and to analyze the results of project activity in order to } \\
\text { improve it. }\end{array}$ \\
\hline
\end{tabular}

Table 2. Level of development of components of project competence in experimental and control groups before experiment

\begin{tabular}{|l|c|c|c|c|c|c|}
\hline \multirow{2}{*}{ Project competence } & \multicolumn{3}{|c|}{ Experimental group } & \multicolumn{3}{c|}{ Control group } \\
\cline { 2 - 7 } & $\begin{array}{c}\text { Low level, } \\
\text { \% }\end{array}$ & $\begin{array}{c}\text { Middle level, } \\
\text { \% }\end{array}$ & $\begin{array}{c}\text { High level, } \\
\text { \% }\end{array}$ & $\begin{array}{c}\text { Low level, } \\
\text { \% }\end{array}$ & $\begin{array}{c}\text { Middle level, } \\
\text { \% }\end{array}$ & $\begin{array}{c}\text { High level, } \\
\%\end{array}$ \\
\hline Cognitive component & 40.3 & 38.6 & 21.1 & 39.3 & 39.2 & 21.5 \\
\hline Operational component & 55.7 & 28.6 & 15.7 & 37.7 & 39.2 & 23.1 \\
\hline Communicative component & 43.2 & 33.2 & 23.6 & 42.1 & 30.6 & 27.3 \\
\hline Reflexive component & 56.3 & 29.3 & 14.4 & 43.7 & 35.1 & 21.2 \\
\hline
\end{tabular}

Table 3. Level of development of components of project competence in experimental and control groups after experiment

\begin{tabular}{|l|c|c|c|c|c|c|}
\hline \multirow{2}{*}{ Project competence } & \multicolumn{3}{|c|}{ Experimental group } & \multicolumn{3}{c|}{ Control group } \\
\cline { 2 - 7 } & $\begin{array}{c}\text { Low level, } \\
\text { \% }\end{array}$ & $\begin{array}{c}\text { Middle level, } \\
\text { \% }\end{array}$ & $\begin{array}{c}\text { High level, } \\
\text { \% }\end{array}$ & $\begin{array}{c}\text { Low level, } \\
\text { \% }\end{array}$ & $\begin{array}{c}\text { Middle level, } \\
\text { \% }\end{array}$ & $\begin{array}{c}\text { High level, } \\
\text { \% }\end{array}$ \\
\hline Cognitive component & 13.2 & 37.4 & 49.4 & 41.4 & 38.5 & 20.1 \\
\hline Operational component & 7.9 & 27.1 & 65.0 & 34.4 & 43.2 & 22.4 \\
\hline $\begin{array}{l}\text { Communicative } \\
\text { component }\end{array}$ & 8.6 & 23.6 & 67.8 & 33.1 & 37.7 & 29.2 \\
\hline Reflexive component & 5.4 & 27.8 & 66.8 & 42.4 & 37.1 & 20.5 \\
\hline
\end{tabular}


Results of input and final diagnostics of the formation of project competence in control and experimental groups showed a significant dynamic of the development of project competence in experimental group. It proves the effectiveness of the experimental work.

\section{Conclusion}

Graduates of engineering universities should possess project competence which is expressed in ability to create a new product in the form of a technical model or technology, to carry out creative research activities in accordance with educational plan, to make decisions, to evaluate the effectiveness of these decisions, to establish connections between different areas of engineering professional activity, and also to think logically and figuratively.

Project competence is characterized by the ability of future engineers to apply knowledge, skills and personal qualities that ensure readiness for implementation of project activity and awareness of personal responsibility for the results of this activity. Formation of project competence of future engineer using blended learning is a focused process of mastering ways to solve educational and professional problems. Application of blended learning in formation of project competence of future engineers contributes to the formation of work skills, group work, mutual assistance and communicative competencies. It contributes to ability to select reliable data sources, creativity, ability to rethink existing information, to synthesize new ideas and solutions. Thus, blended learning has great potential for creating new ways to use digital technologies in engineering education, the purpose of which is not only to increase effectiveness of training but also to form project competence of future engineers.

\section{References}

[1] Bakša, V. Z., \& Bednjanec, A. (2019). Project teaching in computer subjects. Paper presented at the 2019 42nd International Convention on Information and Communication Technology, Electronics and Microelectronics, MIPRO 2019 - Proceedings, 633-636. https://doi.org/10.23919/mipro.2019.8756840

[2] Bubnov, Y. A., Gaidar, K. M., Fedorov, V. A., Berezhnaya, I. F., \& Galustyan, O. V. (2018). Organization of the training process based on modular and rating technology at higher educational institution. Espacios, 39(25)

[3] Chen, J. (2019). Exploration and application of SPOC-based blended teaching mode in comprehensive English course. Paper presented at the Journal of Physics: Conference Series, , 1237(2) https://doi.org/10.1088/1742-6596/1237/2/022115

[4] Galustyan, O. V., Borovikova, Y. V., Polivaeva, N. P., Kodirov, B. R., \& Zhirkova, G. P. (2019). E-learning within the field of andragogy. International Journal of Emerging Technologies in Learning, 14(9), 148-156. https://doi.org/10.3991/ijet.v14i09. $\underline{10020}$

[5] Galustyan, O. V., Gaidar, K. M., Aleshina, S. A., Ksenofontova, A. N., \& Ledeneva, A. V. (2018). Development of group subjectivity of pupils within collaborative activities. TEM Journal, 7(4), 854-858. doi:10.18421/TEM74-25 
[6] Galustyan, O. V., Lazukin, V. F., Petelin, A. S., \& Ostapenko, V. S. (2018). Diagnostic Activity of Teachers at High School. Revista Espacios, Vol. 39(N 10). Retrieved from http http://www.revistaespacios.com/a18v39n10/18391024.html

[7] Galustyan, O. V., Meshcheryakova, E. I., Larina, T. V., Bakleneva, S. A., \& Krivotulova, E. V. (2018). Self-regulated learning of students at university. Espacios, 39(23)

[8] García-Guardia, M., Ayestarán-Crespo, R., López-Gómez, J., \& Tovar-Vicente, M. (2019). Educating the gifted student: Eagerness to achieve as a curricular competence. Comunicar, 27(60), 19-28. https://doi.org/10.3916/c60-2019-02

[9] Ghonim, M., \& Eweda, N. (2019). Instructors' perspectives on the pedagogy of architectural graduation projects: A qualitative study. Frontiers of Architectural Research, 8(3), 415-427. https://doi.org/10.1016/j.foar.2019.01.007

[10] Ibrahim, M. M., \& Nat, M. (2019). Blended learning motivation model for instructors in higher education institutions. International Journal of Educational Technology in Higher Education, 16(1) https://doi.org/10.1186/s41239-019-0145-2

[11] Korkmaz, Ö., Kösterelioğlu, M., \& Kara, M. (2018). A validity and reliability study of the engineering and engineering education attitude scale (EEAS). International Journal of Engineering Pedagogy, 8(5), 44-57. https://doi.org/10.3991/ijep.v8i5.8667

[12] Kravchenko, E. V., Galustyan, O. V., Kovtunenko, L. V., \& Kolosova, L. A. (2018). Pedagogical practice of students. Espacios, 39(17)

[13] Mayes, R., Gallant, B., \& Fettes, E. (2018). Interdisciplinary STEM through engineering design-based reasoning. International Journal of Engineering Pedagogy, 8(3), 60-68. https://doi.org/10.3991/ijep.v8i3.8026

[14] Michalak, D., \& Rozmus, M. (2020). Methods and tools for acquiring high-quality skills in digital era - innovative practices and results from 3DSPEC and e-MOTIVE projects https://doi.org/10.1007/978-3-030-20135-7 26

[15] Pankratova, E. A. (2019). Contribution of cross-cultural projects in foreign language education of university students (by the example of Murom institute). Paper presented at the IOP Conference Series: Earth and Environmental Science, 272(3) https://doi.org/10.1088/1755-1315/272/3/032140

[16] Petelin, A. S., Galustyan, O. V., Prosvetova, T. S., Petelina, E. A., \& Ryzhenkov, A. Y. (2019). Application of educational games for formation and development of ICT competence of teachers. International Journal of Emerging Technologies in Learning, 14(15), 193-201. https://doi.org/10.3991/ijet.v14i15.10572

[17] Ramirez-Arellano, A. (2019). Students learning pathways in higher blended education: An analysis of complex networks perspective. Computers and Education, 141 https://doi.org/10.1016/j.compedu.2019.103634

[18] Rasheed, R. A., Kamsin, A., \& Abdullah, N. A. (2020). Challenges in the online component of blended learning: A systematic review. Computers and Education, 144 https://doi.org/10.1016/j.compedu.2019.103701

[19] Ravarini, A., Locoro, A., \& Martinez, M. (2020). Digital transformation projects maturity and managerial competences: A model and its preliminary assessment. Paper presented at the Lecture Notes in Information Systems and Organisation, 33 261-272. https://doi.org/10.1007/978-3-030-23665-6_19

[20] Sagitova, R. N., Gilmanshin, I. R., \& Akchurina, A. R. (2019). Project activity as a stage of continuous engineering and technical education. Paper presented at the IOP Conference Series: Materials Science and Engineering, 570(1) https://doi.org/10.1088/1757$\underline{899 x / 570 / 1 / 012086}$ 
[21] Sandanayake, T. C. (2019). Promoting open educational resources-based blended learning. International Journal of Educational Technology in Higher Education, 16(1) https://doi.org/10.1186/s41239-019-0133-6

[22] Sgro, F., Quinto, A., Platania, F., \& Lipoma, M. (2019). Assessing the impact of a physical education project based on games approach on the actual motor competence of primary school children. Journal of Physical Education and Sport, 19, 781-786. doi:10.7752/jpes. 2019.s3111

[23] Smith, C. M., \& Johnson, C. S. (2019). Preparing nurse leaders in nursing professional development: Project planning and management. Journal for Nurses in Professional Development, 35(3), 160-162. https://doi.org/10.1097/nnd.0000000000000549

[24] Taheri, P. (2018). Project-based approach in a first-year engineering course to promote project management and sustainability. International Journal of Engineering Pedagogy, 8(3), 104-119. https://doi.org/10.3991/ijep.v8i3.8573

[25] Wood, R., McGlashan, A., Moon, C. -., \& Kim, W. Y. (2018). Engineering education in an integrated setting. International Journal of Engineering Pedagogy, 8(3), 17-27. https://doi.org/10.3991/ijep.v8i3.7857

[26] Zaher, A. A., \& Damaj, I. W. (2018). Extending STEM education to engineering programs at the undergraduate college level. International Journal of Engineering Pedagogy, 8(3), 416. https://doi.org/10.3991/ijep.v8i3.8402

[27] Zydney, J. M., Warner, Z., \& Angelone, L. (2020). Learning through experience: Using design-based research to redesign protocols for blended synchronous learning environments. Computers and Education, 143 https://doi.org/10.1016/j.compedu.2019.103678

\section{$7 \quad$ Authors}

Olga V. Galustyan is Professor of the Department of Education and Pedagogical Sciences of Southern Federal University, Rostov-on-Don, Russia. Email: olga.galustyan@gmail.com

Alexey V. Solyankin is Associate Professor of the Department of Industrial Ecology and Safety of State University named after A.N. Kosygin, Moscow, Russia.

Alina V. Skripkina is Professor of Educational and Scientific Center of Psychology of Professional Activity of Moscow University of the Ministry of Internal Affairs of the Russian Federation named after V. Y. Kikot, Moscow, Russia.

Evgeny A. Shchurov is Associate Professor of Moscow University of the Ministry of Internal Affairs of the Russian Federation named after V. Y. Kikot, Moscow, Russia.

Tatyana V. Semeshkina is Associate Professor of State University named after A.N. Kosygin, Moscow, Russia.

Anastasia V. Ledeneva is Associate Professor of Department of Pedagogy of Higher School of Orenburg State Pedagogical University, Orenburg, Russia.

Article submitted 2019-11-07. Resubmitted 2020-02-29. Final acceptance 2020-03-01. Final version published as submitted by the authors. 


iJEP - Vol. 10, No 3, 2020

Imprint

iJEP - International Journal of Engineering Pedagogy

Online issue: http://www.i-jep.org

Editor-in-Chief

Matthias Christoph Utesch, TU München, Germany

Executive Editor

Michael E. Auer, CTIVillach, Austria

Deputy Editor-in-Chief

Matthias Gottlieb, TU München, Germany

Senior Editor

Klaus-Tycho Foerster, University of Vienna, Austria

Editors

José Couto Marques, University of Porto, Portugal

Tatiana Yurievna Polyakova, MADI, Moscow, Russian Federation

Istvan Simonics, Obuda University, Hungary

\section{Technical Editor}

Sebastian Schreiter, Lagorce, France

\section{Editorial Board}

Teresa L Larkin, American University, United States

Eleonore Lickl, HBLVA, Vienna, Austria

Maria Teresa Restivo, University of Porto, Portugal

Tiia Rüütmann, Tallinn University of Technology, Estonia

Phillip A. Sanger, Purdue University College of Technology, United States

Alexander Solovyev, MADI, Moscow, Russian Federation

James Wolfer, Indiana University South Bend, United States

Axel Zafoschnig

\section{Indexing}

International Journal of Engineering Pedagogy (iJEP) is indexed

in Elsevier Scopus, Clarivate Analytics ESCI, EBSCO, DOAJ and DBLP.

\section{Publication Frequency}

Bi-monthly (January, March, May, July, September, November)

\section{ISSN}

2192-4880

\section{Publisher}

International Society of Engineering Education (IGIP)

Europastrasse 4

A-9524 Villach

Austria 